\title{
Case Report: Efficient Avoidance of Hospitalization for Diabetic Ketosis Utilizing Technosphere Inhaled Insulin
}

\author{
David S. H. Bell • Edison Goncalves
}

Received: January 27, 2020 / Published online: April 9, 2020

(C) The Author(s) 2020

\section{ABSTRACT}

We describe the use of inhaled insulin for the therapy of diabetic ketosis/ketoacidosis in a patient with type 1 diabetes. In this situation high insulin levels are needed to metabolize ketone bodies and avoid hospitalization. Technosphere inhaled insulin (TI) may be an alternative to subcutaneously injected fast-acting insulins, not only because of its rapid onset of action but also lack of stacking leading to lateonset hypoglycemia. In conclusion, TI may well be more efficacious and safer in the outpatient management of diabetic ketosis/ketoacidosis than standard subcutaneously injected rapidacting insulin.

Keywords: Diabetic ketosis; Ketoacidosis treatment; Technosphere inhaled insulin

Enhanced digital features To view digital features for this article go to https://doi.org/10.6084/m9.figshare. 12022854 .

D. S. H. Bell $(\bowtie) \cdot$ E. Goncalves

Southside Endocrinology and Diabetes and Thyroid Associates, Birmingham, AL, USA

e-mail: dshbell@yahoo.com

\section{Key Summary Points}

Diabetic ketoacidosis frequently requires hospital admission which is costly and disruptive to patients.

Outpatient treatment can be risky because of erratic subcutaneous insulin absorption and stacking.

We report a patient treated successfully for diabetic ketoacidosis/ketosis with inhaled insulin in the outpatient setting.

This unique use for inhaled insulin needs to be tested in a randomized controlled trial.

\section{INTRODUCTION}

Technosphere inhaled insulin (human insulin, TI) is not currently indicated for diabetic ketoacidosis (DKA) [1]. In phase III clinical trials of patients with type 1 diabetes, DKA was more common with inhaled insulin $(0.43 \%$ versus $0.14 \%$ ), probably because of the longer action of the comparator insulin (aspart) [2]. However, in a situation where high insulin levels are rapidly needed to metabolize ketone bodies and avoid 
hospitalization, TI may be an alternative to subcutaneously injected fast-acting insulins, not only because of its rapid onset of action and shorter half-life but also the lack of stacking leading to late-onset hypoglycemia $[2,3]$.

We present a case of DKA in a patient with type 1 diabetes where administration of inhaled TI resolved the ketosis without the use of shortacting subcutaneously or intravenously administered insulin and eliminated an emergency room/hospital visit. Patient permission for this publication was obtained.

\section{CASE PRESENTATION}

A 64-year-old woman with a history of type 1 diabetes diagnosed at age 5 . Her current diabetic therapy included once daily degludec insulin and inhaled TI 3-6 times daily. She had excellent glycemic control (most recent HbA1c 6.8\%) without severe or frequent hypoglycemia. Her only diabetic complication was mild distal symmetrical polyneuropathy.

Following a Christmas party, she developed severe gastroenteritis and uncontrolled vomiting which progressed to severe ketosis (urinary ketone bodies, acetoacetate, and acetone exceeding $160 \mathrm{mg} / \mathrm{dl}$ ) and severe dehydration. Once her vomiting was corrected with promethazine suppositories (every $4 \mathrm{~h}$ ) and dehydration improved, the severe ketosis persisted in spite of serum glucose levels in the 90-120 mg/ dl range.

With the patient regaining her ability to absorb and maintain oral intake, she was started on inhaled TI, four units every hour. Her glucose was monitored with the Dexcom G6 continuous glucose monitoring device with a goal of $90-150 \mathrm{mg} / \mathrm{dl}$. She was advised to inhale 8 units if her glucose read over $150 \mathrm{mg} / \mathrm{dl}$. After $4 \mathrm{~h}$, no urine ketones were reported, her serum glucose was $105 \mathrm{mg} / \mathrm{dl}$, and she resumed her usual diabetic regimen. In addition, she did not experience any hypoglycemic episodes during the hourly inhaled TI.

Inhaled TI at the lower doses utilized in this patient appears in the plasma within $1 \mathrm{~min}$, with a measurable effect in $12 \mathrm{~min}$, peak effect at $35 \mathrm{~min}$, and return to baseline within $90 \mathrm{~min}$. The intra-patient variability is approximately $28 \%$ (95\% CI 21-42\%) [1]. Even the fast-acting form of aspart insulin $\left(\right.$ Fiasp $\left.^{\circledR}\right)$, which appears by $2.5 \mathrm{~min}$, with a measurable effect in $20 \mathrm{~min}$, and peak effect at $1.5-2 \mathrm{~h}$, only returns to baseline at between 5 and $7 \mathrm{~h}[4,5]$. However, these levels can be severely affected by dehydration, so that not only will the correction of ketosis be delayed but later with rehydration high serum insulin levels can lead to hypoglycemia and hypokalemia. Ideally DKA should be treated intravenously with insulin where steady serum insulin levels can be achieved avoiding those complications [6]. However, in the home setting this is rarely possible and the less efficacious subcutaneous route is the only alternative. This results in an increased likelihood of an emergency room visit or a hospitalization.

Access to inhaled TI in the home setting may be more effective and less risky in preventing ketoacidosis, hospitalization, and/or emergency room visits [7, 8]. However, to be approved for the treatment of DKA, a prospective, randomized study comparing the efficacy and safety of TI insulin with intravenously administered insulin would have to be performed.

\section{CONCLUSION}

Technosphere inhaled insulin may be more efficacious and safer in the outpatient management of diabetic ketosis/ketoacidosis than standard subcutaneously injected rapid-acting insulin. This hypothesis should be validated by a randomized, prospective study.

\section{ACKNOWLEDGEMENTS}

Funding. No funding or sponsorship was received for this study or publication of this article.

Authorship. All named authors meet the International Committee of Medical Journal Editors (ICMJE) criteria for authorship for this article, take responsibility for the integrity of the work as a whole, and have given their approval for this version to be published. 
Disclosures. David S. H. Bell is on the Speaker's bureau of Novo-Nordisk and Mannkind Corporation. David S.H. Bell is a member of the journal's Editorial Board. Edison Goncalves is on the speaker's bureau of NovoNordisk.

Compliance with Ethics Guidelines. Patient permission for this publication was obtained.

Data Availability. Data sharing is not applicable to this article as no datasets were generated or analyzed during the current study.

Open Access. This article is licensed under a Creative Commons Attribution-NonCommercial 4.0 International License, which permits any non-commercial use, sharing, adaptation, distribution and reproduction in any medium or format, as long as you give appropriate credit to the original author(s) and the source, provide a link to the Creative Commons licence, and indicate if changes were made. The images or other third party material in this article are included in the article's Creative Commons licence, unless indicated otherwise in a credit line to the material. If material is not included in the article's Creative Commons licence and your intended use is not permitted by statutory regulation or exceeds the permitted use, you will need to obtain permission directly from the copyright holder. To view a copy of this licence, visit http://creativecommons.org/licenses/bync/4.0/.

\section{REFERENCES}

1. Afrezza (insulin human) inhalation powder prescribing information. MannKind Corporation.

2. https://www.diabetesincontrol.com/wp-content/uplo ads/2014/04/www.fda.gov_downloads_AdvisoryCom mittees_CommitteesMeetingMaterials_Drugs_Endoc rinologicandMetabolicDrugsAdvisoryCommittee_UC M390864.pdf Accessed Jan 2020.

3. Bode BW, McGill JB, Lorber DL, et al. Inhaled Technosphere insulin compared with injected prandial insulin in type 1 diabetes: a randomized 24-week trial. Diabetes Care. 2015;38(12):2266-73.

4. Akturk HK, Snell-Bergeon JK, Rewers A, et al. Improved postprandial glucose with inhaled Technosphere insulin compared with insulin aspart in patients with type 1 diabetes on multiple daily injections: the STAT study. Diabetes Technol Ther. 2018;20(10):639-47.

5. Fiasp [package insert]. Plainsboro. NJ: Novo Nordisk; 2018.

6. Heise T, Pieber TR, Danne T, Erichsen L, Haahr H. A pooled analysis of clinical pharmacology trials investigating the pharmacokinetic and pharmacodynamic characteristics of fast-acting insulin aspart in adults with type 1 diabetes. Clin Pharmacokinet. 2017;56(5): 551-9.

7. French Esra K, Donihi Amy C, Korytkowski Mary T. Diabetic ketoacidosis and hyperosmolar hyperglycemic syndrome: review of acute decompensated diabetes in adult patients. BMJ. 2019;365:11114.

8. Heinemann L, Parkin CG. Rethinking the viability and utility of inhaled insulin in clinical practice. J Diabetes Res. 2018;2018:4568903. 